JURNAL ILMIAH ELEKTRONIKA DAN KOMPUTER, Vol.14, No.2, Desember 2021, pp. 216 - 223

p-ISSN : 1907-0012 (print)

e-ISSN : 2714-5417 (online)

http://journal.stekom.ac.id/index.php/elkom

. page 216

\title{
Sistem Informasi Akuntansi Penyusutan Aktiva Tetap Dengan Metode Garis Lurus Pada SMK Muhammadiyah 1 Weleri berbasis Web
}

\author{
Ahmad Asifuddin ${ }^{1}$, Haris Ihsanil Huda ${ }^{2}$, Zaenal Mustofa ${ }^{3}$ \\ ${ }^{1}$ Sistem Informasi, Universitas Sains Dan Teknologi Komputer \\ Jl. Majapahit No. 605, e-mail: ashif@stekom.ac.id \\ ${ }^{2}$ Sistem Informasi, Universitas Sains Dan Teknologi Komputer \\ J1. Majapahit No 605, e-mail: harisxid@gmail.com \\ ${ }^{3}$ Ilmu Komputer,Universitas Sains Dan Teknologi Komputer \\ Jl. Majapahit No. 605 e-mail: zm.tofu@gmail.com
}

ARTICLE INFO

Article history:

Received 31 Oktober 2021

Received in revised form 03 November 2021

Accepted 10 November 2021

Available online 1 Desember 2021

\section{ABSTRACT}

Information technology is a technology used to process data, including processing, obtaining, compiling, storing, manipulating data in various ways to produce relevant, accurate and timely information, which is used for personal, business and government purposes and is strategic information for decision making, in recording fixed assets for example, must be managed properly because the need for the data is frequent intensity, the number of items is not small so it is impossible to memorize, the calculation of depreciation of fixed assets of a company needs to be done at the end of every year because it will affect the book value and depreciation expense on the balance sheet and depreciation expense on fixed assets on the income statement. This depreciation calculation can also be used as a reference in the allocation to purchase new assets if the existing fixed assets can no longer be used.

Obstacles in preparing depreciation reports if not resolved immediately will have a bad impact on schools, for example being late in submitting annual tax reports due to the long preparation of depreciation reports will result in schools being fined for being late in reporting the annual corporate tax return. With the accounting information system for depreciation of fixed assets, it is expected that it will facilitate officers in managing fixed asset data and depreciation reports. The new system that will be designed is web-based, so that it can be accessed at any time by interested parties and makes coordination time more effective.

Keywords: Web, Straight Line Method, Information System

Received Oktober 31, 2021; Revised November 03, 2021; Accepted November 10, 2021 


\section{Latar Belakang}

Teknologi informasi adalah suatu teknologi yang digunakan untuk mengolah data, termasuk memproses, mendapatkan, menyusun, menyimpan, memanipulasi data dalam berbagai cara untuk menghasilkan informasi yang relevan, akurat dan tepat waktu, yang digunakan keperluan pribadi, bisnis dan pemerintahan dan merupakan informasi yang strategis untuk pengambilan keputusan (Sutabri, 2014). Pemanfaatan teknologi secara maksimal akan membantu perusahaan untuk meningkatkan kinerja secara efektif dan efisien. Seperti halnya pencatatan dan pembukuan suatu perusahaan yang dulunya masih menggunakan buku manual yang tebal dan perhitungan kalkulator sekarang sudah banyak beralih pada pemanfaatan komputer dengan software sederhana dalam pengelolaan datanya.

Dalam pencatatan aktiva tetap misalnya, harus dikelola dengan baik karena kebutuhan akan data tersebut intensitasnya sering, jumlah barang yang tidak sedikit sehingga tidak mungkin dihafalkan. Aktiva tetap merupakan salah satu bagian terpenting dalam penentuan berjalannya suatu usaha, dengan mengeluarkan dana yang tidak sedikit tentu perusahaan mengharapkan pemanfaatan barang tersebut secara maksimal. Semakin tahun berjalan tentu nilai jual dan kemanfaatan suatu aktiva tetap terus menurun ataupun menyusut. Penyusutan adalah alokasi yang sistematis atas nilai suatu aktiva tetap yang dapat disusutkan selama masa manfaat aktiva yang bersangkutan (Kusmayadi \& Harti, 2018). Perhitungan penyusutan aktiva tetap suatu perusahaan perlu dilakukan setiap akhir tahun karena akan mempengaruhi nilai buku dan beban penyusutan pada neraca dan beban penyusutan aktiva tetap pada laporan laba rugi. Perhitungan penyusutan ini juga dapat digunakan sebagai acuan dalam pengalokasian untuk membeli aktiva baru apabila aktiva tetap yang ada sudah tidak dapat dimanfaatkan lagi.

SMK Muhamamdiyah 1 Weleri adalah salah satu sekolah menengah kejuruan swasta di Kecamatan Weleri, Kabupaten Kendal. Dalam pengelolaan keuangannya SMK Muhammadiyah 1 Weleri sebagian besar menggunakan Microosoft Excel untuk penyusunan laporannya. Untuk laporan penyusutan aktiva tetap metode penyusutan yang digunakan adalah metode garis lurus. Pada metode garis lurus ini menggabungkan alokasi biaya dengan berlalunya waktu dan mengakui pembebanan periodik yang sama sepanjang umur aktiva tetap (Hery, 2014). Metode ini dipilih karena perhitungannya lebih mudah dan juga dapat digunakan untuk laporan pajak tahunan, sehingga petugas tidak perlu menyajikan laporan penyusutan dengan 2 metode yang berbeda.

kesalahan perhitungan yang akan berpengaruh pada nilai akhir aktiva tetap. Penyusunan laporan data aktiva tetap serta laporan penyusutan memerlukan waktu yang lama dan tidak tepat waktu dalam penyajiannya karena penyusunan laporan harus berkoordinasi dengan beberapa bagian, selain itu laporan yang dihasilkan juga belum tersaji secara detail, baik berurutan secara abjad maupun berdasarkan tahun pembelian aktiva tetap, sehingga laporan yang tersaji belum memberikan informasi data aktiva dan penyusutan secara lengkap. Data aktiva tetap yang telah habis masa manfaatnya langsung dihapuskan dalam laporan, sehingga aktiva tetap yang habis masa manfaatnya namun masih dalam kondisi baik sudah terhapuskan, dan aktiva tetap yang masih ada manfaatnya tetapi barang sudah rusak masih tercantum dalam laporan.

Kendala penyusunan laporan penyusutan jika tidak segera teratasi akan menimbulkan dampak yang buruk bagi sekolah, misalnya terlambat mengumpulkan laporan pajak tahunan karena penyusunan laporan penyusutan yang lama akan membuat sekolah dikenakan denda karena telat melaporkan SPT tahunan badan. Dengan adanya sistem informasi akuntansi penyusutan aktiva tetap diharapkan akan memudahkan petugas dalam mengelola data aktiva tetap dan laporan penyusutan. Sistem baru yang akan dirancang adalah berbasis web, sehingga dapat diakses setiap saat oleh pihak yang berkepentingan dan membuat waktu koordinasi menjadi lebih efektif.

Sistem Informasi Akuntansi Penyusutan Aktiva Tetap Dengan Metode Garis Lurus Pada SMK Muhammadiyah 1 Weleri berbasis Web (Ahmad Asifuddin) 
Berdasarkan uraian diatas penulis bermaksud untuk mengangkat permasalahan laporan penyusutan aktiva tetap yang akan disajikan dalam bentuk penelitian dengan judul "Sistem Informasi Akuntansi Penyusutan Aktiva Tetap Dengan Metode Garis Lurus Pada SMK Muhammadiyah 1 Weleri”.

\section{Tinjauan Pustaka}

2.1. Jurnal Perancangan Sistem Informasi Aktiva Tetap pada PT Sejahtera Jaya Mandraguna Jambi oleh Hendra Kurniawan dan Joni Devitra Tahun 2016 dalam penelitian ini disimpulkan bahwa pengelolaan data aktiva tetap membutuhkan ketelitian karena menggunakan Microsoft Excel, dengan membuat sistem informasi pengelolaan data aktiva menjadi lebih efektif. Pada penelitian ini sistem informasi menghasilkan output laporan penyusutan aktiva tetap dan laporan aktiva tetap. Laporan penyusutan disajikan dalam metode garis lurus, metode saldo menurun dan metode jumlah angka tahun.

2.2 Jurnal Perancangan Sistem Informasi Penyusutan Aktiva Tetap Menggunakan Metode Garis Lurus Pada Kopkar Bina Khatulistiwa oleh Fatmawati Isnaini, Fherna Aisyah, Dian Widiarti dan Donaya Pasha Tahun 2017 penelitian ini dirancang menggunakan aplikasi visual basic dengan output yang dihasilkan berupa laporan aktiva tetap dan laporan penyusutan dengan metode garis lurus. Karyawan bagian pembukuan dapat mengolah data penyusutan aktiva tetap yang akan menghasilkan laporan penyusutan yang dibutuhkan bagi pengguna. Selain itu, data penyusutan aktiva tetap dilaporkan oleh koordinator dalam RUPS untuk menilai penyusutan aktiva tetap sebagai oposional dan asset perusahaan yang mengeluarkan biaya.

2.3 Pengertian Sistem adalah suatu jaringan kerja dari prosedur-prosedur yang saling berhubungan, berkumpul bersama-sama untuk melakukan kegiatan atau untuk melakukan sasaran yang tertentu. Supaya sistem itu dikatakan sistem yang baik memiliki karakteristik, yaitu:

a. Komponen

b. Batasan sistem (boundary)

c. Lingkungan luar sistem (environment)

d. Penghubung sistem (interface)

e. Masukan sistem (input)

f. Keluaran sistem (output)

g. Pengolah sistem

h. Sasaran sistem (Hutahaean, 2016) i.

2.4 Pengertian Data Menurut Gordon B. Davis (1991), Data adalah bahan mentah bagi informasi, dirumuskan sebagai kelompok lambang-lambang tidak acak menunjukkan jumlah-jumlah, tindakan-tindakan, hal-hal dan sebagainya. Metode pengambilan data dapat melalui:

a. Pengamatan sendiri secara langsung

b. Wawancara

c. Perkiraan korespondensi

d. Melalui daftar pertanyaan. (Hutahaean, 2016)

2.5 Pengertian Informasi adalah data yang diolah menjadi bentuk yang lebih berguna dan lebih berarti bagi penerimanya. Sumber informasi adalah data. Data kenyataan yang menggambarkan suatu kejadian-kejadian dan kesatuan nyata. Kejadian-kejadian (event) adalah kejadian yang terjadi pada saat tertentu. Suatu informasi dikatakan lebih bernilai jika manfaatnya lebih efektif dibandingkan dengan biaya mendapatkannya. (Hutahaean, 2016) Biaya informasi terdiri dari:

a. Biaya perangkat keras

b. Biaya untuk analisis

c. Biaya untuk tempat dan faktor kontrol lingkungan

JURNAL ILMIAH ELEKTRONIKA DAN KOMPUTER Vol. 14, No. 2, Desember 2021 : 216 - 223 
d. Biaya perubahan

e. Biaya operasi. (Hutahaean, 2016)

2.6 Pengertian Website dapat diartikan sebagai kumpulan halaman yang berisi informasi data digital berupa teks, gambar, animasi, suara dan video atau gabungan dari semuanya yang disediakan melalui jalur koneksi internet sehingga dapat diakses dan dilihat oleh semua orang di seluruh dunia. Halaman website dibuat menggunakan bahasa standar yaitu HTML (Hyper Text Mark up Language). Script HTML ini akan diterjemahkan oleh web browser sehingga dapat ditampilkan dalam bentuk informasi yang dapat dibaca oleh semua orang. (Abdulloh, 2018)

2.7 Pengertian Pemrograman Web (web programming) dapat diartikan sebagai kegiatan pembuatan program atau aplikasi berbasis web menggunakan bahasa pemrograman tertentu sehingga dapat memproses data dan menghasilkan informasi sesuai yang dikehendaki oleh pemilik website. (Abdulloh, 2018)

Bahasa pemrograman web yang biasa digunakan diantaranya adalah sebagai berikut:

a. HTML, berperan sebagai pembentuk struktur halaman website yang menempatkan setiap elemen website sesuai layout yang diinginkan,

b. CSS, berperan sebagai pembentuk desain website dengan mengatur setiap elemen HTML agar tampil menarik pada browser.

c. PHP, berperan sebagai pemroses data pada sisi server sesuai yang diminta oleh client menjadi informasi yang siap ditampilkan, juga sebagai penghubung aplikasi web dengan basis data.

d. SQL, berperan sebagai bahasa yang mengatur transaksi data antara aplikasi dengan database sebagai tempat penyimpanan data.

e. JavaScript, sebagai bahasa yang memproses data pada sisi client serta dapat memanipulasi HTML dan CSS secara dinamis. (Abdulloh, 2018)

\subsection{Pengertian Web Server (XAMPP)}

Web server merupakan perangkat lunak yang berfungsi untuk menerima permintaan (request) melalui protokol HTTP atau HTTPS dari client kemudian mengirimkan kembali dalam bentuk halaman-halaman web. Contoh yang termasuk web server adalah Apache. Salah satu paket yang sudah berisi Apache, PHP, MySQL adalah XAMPP (X(windows/linux) Apache MySQL PHP Perl). (Abdulloh, 2018)

\subsection{Pengertian PHP}

PHP ( Hyperterxt Preprocessor ) yaitu bahasa pemrograman web yang dapat disisipkan dalam skrip HTML dan bekerja di sisi server. Tujuan penggunaan PHP adalah membantu para pengembang web untuk membuat web dinamis yang cepat. Agar dapat menjalankan PHP harus menyediakan perangkat lunak berikut:
a. Web Server (Apache)
b. PHP Server
c. Database Server (MySQL) (Abdulloh, 2018)

2.10 MySQL merupkan database yang paling umum digunakan dalam pemrograman PHP adalah MySQL. Dengan database, data yang diproses oleh PHP dapat disimpan dan dapat digunakan setiap saat. (Abdulloh, 2018)

Multi User adalah suatu sistem dipakai bersama oleh banyak user (pengguna sistem). (Heriyanto, Andika, \& Rajabi, 2018) 


\section{Metode Penelitian}

Metode penelitian yang dilakukan dalam penelitian ini adalah menggunakan metode penelitian dan pengembangan (Research \& Development) dengan metode pengembangan sistem Prototyping untuk menghasilkan produk dalam bentuk Prototype. Sebuah Prototype akan memberikan sebuah gambaran tentang cara kerja sistem yang akan berfungsi dalam bentuk lengkapnya.

Dalam penelitian ini produk yang dihasilkan berupa Sistem Informasi Akuntansi Penyusutan Aktiva Tetap. Langkah-langkah penelitian dan pengembangan ditunjukkan pada gambar berikut ini:

Gambar Langkah-langkah penggunaan metode Research and Development

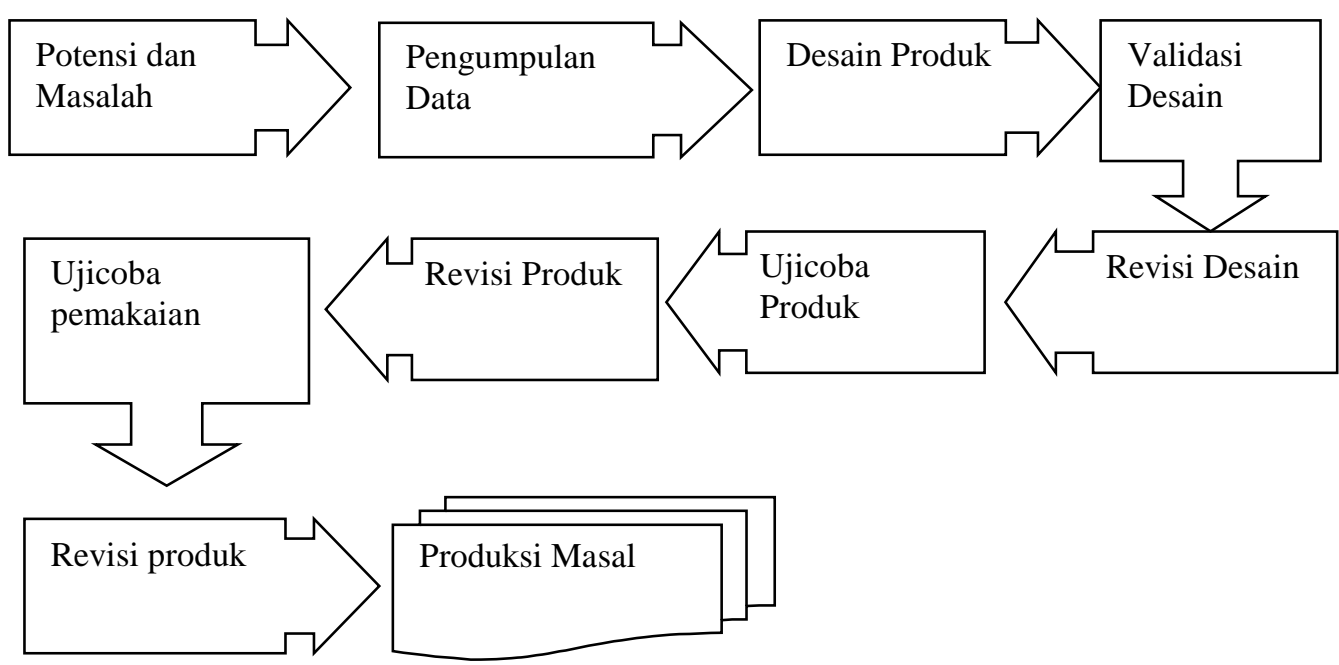

Gambar 1 Bagan Alur Model Pengembangan R\&D

(Sumber :Sugiyono, 2014)

\section{Hasil Dan pembahasan}

Tampilan Data Akun

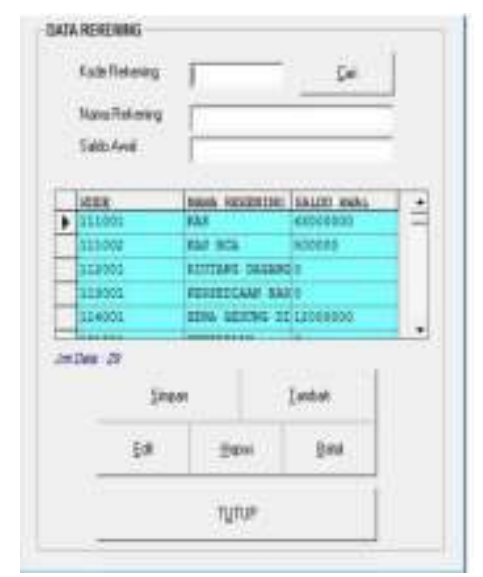

Gambar 2 Tampilan Data Barang

JURNAL ILMIAH ELEKTRONIKA DAN KOMPUTER Vol. 14, No. 2, Desember 2021 : 216 - 223 
Tampilan Input Data Aset

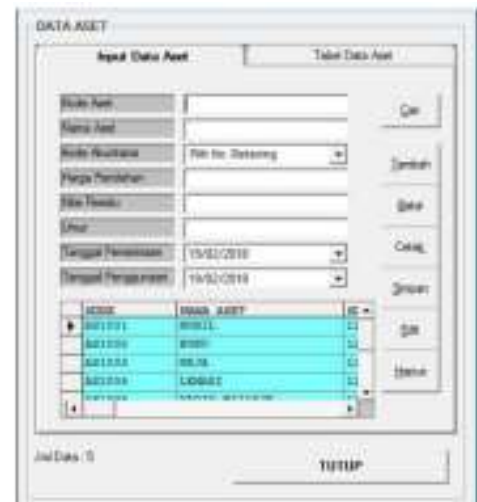

Gambar 3 Tampilan Input Data Aset

Tampilan Input Penyusutan Aset

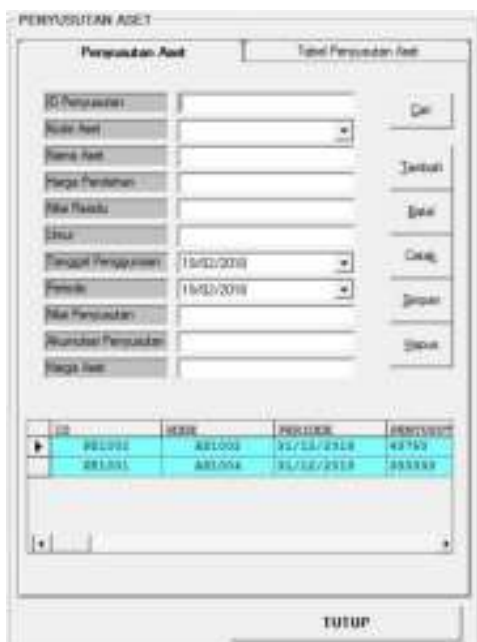

Gambar 4 Tampilan Input Penyusutan Aset

Form yang digunakan untuk mencatat transaksi penyusutan aktiva tetap setiap periode perhitungan dalam aplikasi Sistem Informasi Penyusutan

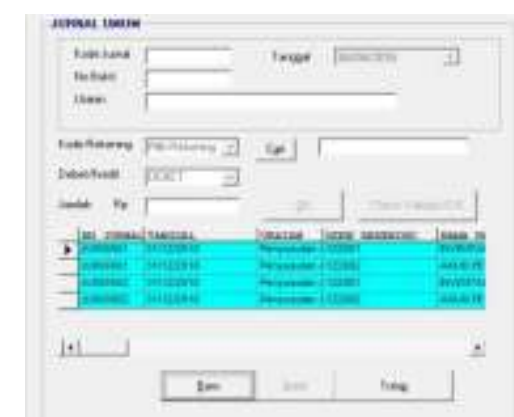

Gambar 5Tampilan Input Jurnal 
Laporan Data Aset

\begin{tabular}{|c|c|c|c|c|c|c|}
\hline Kode & Nama Aset & $\begin{array}{c}\text { Harga } \\
\text { Perolehas }\end{array}$ & $\begin{array}{l}\text { Nilai } \\
\text { Residu }\end{array}$ & Unur & $\begin{array}{c}\text { Tanggal } \\
\text { Peneriman }\end{array}$ & $\begin{array}{c}\text { Tanggal } \\
\text { Pengguaaan }\end{array}$ \\
\hline A5000001 & MOBIL & 230.000 .000 & 100.000 .000 & 8 & $5 \cdot \tan -18$ & $6-\tan -2018$ \\
\hline AS000002 & BUKU & 200.000 & 25.000 & 3 & $23-\mathrm{Mar}-18$ & $23 \cdot \mathrm{Mar} \cdot 2018$ \\
\hline A5000003 & MEIA & 3.650 .000 & 550.000 & 2 & $26-\mathrm{Mar}-18$ & $27-\mathrm{Max}-2018$ \\
\hline AS000004 & [EMAR] & 3.000 .000 & 500.000 & 5 & 12-Met-18 & 12-Mei-2018 \\
\hline AS000005 & VARLO H2223IK & 19.000 .000 & 3.500 .000 & 4 & $30-\mathrm{Mar}-18$ & $30-M a r \cdot 2018$ \\
\hline
\end{tabular}

Tampilan Jurnal

\begin{tabular}{|c|c|c|c|c|c|c|c|}
\hline so $\pi R$ & TANGGAL & No BuK & URAIAN & KODE & NAMA AKUN & DEBET & KREDIT \\
\hline 30000001 & $31 / 12 / 2010$ & DR1001 & Panyagutan Anet Lman: & 122001 & INVzNTARIs rakton & 393.233 & 8 \\
\hline 20000001 & 21/12/2010 & DE1001 & Desyususea Aget LFMaRt & 122002 & AKUM, , DERYUT, INV, KaKTOR & o & 339.239 \\
\hline 30000002 & $31 / 12 / 2010$ & F81002 & Penyagutan daet BURW & 122001 & TRVENTARIS EARTOR & 43.760 & 0 \\
\hline 50000002 & $31 / 12 / 2010$ & 281002 & Denyusutsn anet sukV & 122002 & 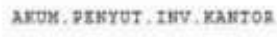 & 0 & 43.750 \\
\hline 50000003 & $31 / 12 / 2019$ & PBO02 & Penghentian aset BOXU & 111001 & gas & 156.250 & 9 \\
\hline 50000003 & $31 / 12 / 2019$ & PHOO2 & Denghensian Axet DUKU & 122002 & 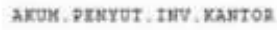 & 49.730 & a \\
\hline 50000003 & $31 / 12 / 2018$ & vH002 & Denghenstan Aaet guKV & 122001 & INVENTA2:S KanToR & ? & 200. \\
\hline
\end{tabular}

Tampilan Laporan Data Penyusutan Aset

\begin{tabular}{|c|c|c|c|c|c|}
\hline & JUL BULAN & PERIODE & PENYUSETAN & AKUMELAS & NILAI AKHIR ASE T \\
\hline KODE - NAMA ASET & \multicolumn{2}{|l|}{ AS000001 - MOBLL } & ID & PE000002 & \\
\hline HARGA PEROLEHAX & \multicolumn{2}{|l|}{ Rp 230.000 .000} & & GL AWAL PENGGEXAAX & 06.J2e:2018 \\
\hline NILAI RESDC & Rp 1000000.000 & & & & \\
\hline UMUR & 8 & & & & \\
\hline & 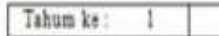 & $31 . D+1-2018$ & 43,730 & 43750,00 & Rp $\quad 20,0956250,00$ \\
\hline
\end{tabular}

\section{Kesimpulan dan Saran}

Berdasarkan pembahasan yang telah dipaparkan pada bab-bab sebelumnya maka dapat ditarik beberapa kesimpulan sebagaiAplikasi sistem informasi akuntansi penyusutan aset tetap dengan metode garis lurus dapat digunakan dan membantu dalam mengelola aset tetap dan memberikan informasi yang lengkap dan akurat mengenai nilai aset setiap periode. 
Abdulloh, R. (2018). 7 in 1 Pemrograman Web untuk Pemula. Jakarta: Penerbit PT Alex Media Komputindo.

Heriyanto, Andika, M., \& Rajabi, A. N. (2018). Komputer dan Jaringan Dasar Program Keahlian Komputer dan Informatika SMK/MAK Kelas X. Bogor: Yudhistira.

Hery. (2014). Akuntansi Dasar 1 \& 2. Jakarta: Grasindo.

[Hutahaean, J. (2016). Konsep Sistem Informasi. Yogyakarta: Penerbit Deepublish.

Isnaini, F., Aisyah, F., Widiarti, D., \& Pasha, D. (2017). Perancangan Sistem Informasi Akuntansi Penyusutan Aktiva Tetap Menggunakan Metode Garis Lurus Pada Kopkar Bina Khatulistiwa. Jurnal TEKNOKOMPAK Vol 11 No 2, 50-54.

Kurniawan, H., \& Devitra, J. (2016). Perancangan Sistem Informasi Aktiva Tetap Pada PT Sejahtera Jaya Mandraguna Jambi. Jurnal Manajemen Sistem Informasi Vol 1 No 2 , 215-226.

Kusmayadi, \& Harti, D. (2018). Praktikum Akuntansi Lembaga/Instansi Pemerintah Komptensi Keahlian Akuntansi dan Keuangan Lembaga untuk SMK/MAK Kelas XII. Semarang: Penerbit Erlangga.

MADCOMS. (2016). Adobe Dreamweaver CS6 dan PHP-MySQL untuk Pemula. Madiun: Penerbit Andi.

Pratama, I. W., \& Nurlela, I. (2018). Sistem Informasi Akuntansi Aset Tetap Kendaraan Pada CV Bumi Waras di Bandar Lampung. Jurnal Sistem Informasi (JUSINTA) Vol 1 No 1, 56-66.

Republik Indonesia. (2008). Undang-Undang RI Nomor 38 Tahun 2008 Tentang Perubahan Keempat Atas Undang-Undang Nomor 7 Tahun 1983 Tentang Pajak Penghasilan. Jakarta: Sekretariat Negara.

Romney, M. B., \& Steinbart, P. J. (2015). Accounting Information System Edisi 13 Bahasa Indonesia. Jakarta Selatan: Penerbit Salemba Empat.

Sugiyono. (2016). Metodologi Penelitian Kuantitatif, Kualitatif dan R\&D. Bandung: Penerbit Alfabeta.

Sukardi. (2015). Metodologi Penelitian Pendidikan. Jakarta: PT Bumi Aksara.

Sutabri, T. (2014). Pengantar Teknologi Informasi. Yogyakarta: Penerbit Andi. 